Сања П. Перић

Универзитет у Новом Саду

Филозофски факултет

Студент докторских студија
УДК 821.163.41-31.09 Сремац С. 821.163.41-31.09 Матавуљ С. https://doi.org/10.18485/uzdanica.2020.17.1.2

Оригинални научни рад Примљен: 28. фебруар 2020.

Прихваћен: 1. јун 2020.

\title{
ГОЗБЕНЕ СЛИКЕ У РОМАНИМА ПОП ЋИРА И ПОП СПИРА СТЕВАНА СРЕМЦА И БАКОЊА ФРА БРНЕ СИМЕ МАТАВУЉА ${ }^{1}$
}

$A \bar{u} c \bar{u} р а \kappa \bar{u}: \mathrm{У}$ раду се анализирају гозбене слике у романима српских реалиста 19. века, Симе Матавуља и Стевана Сремца, при чему је фокус на односу гозбених слика и јунака који у гозби (не) уживају. Вишезначност и вишеслојност гастрономских тема у анализираним романима отвара питање о функционалности гозбених слика и видовима њиховог испољавања, како на микроплану књижевног дела, тако и у ширем контексту европске књижевности. Као посебно значајно испоставља се Раблеово дело и Бахтинова анализа гозбених слика у роману и народној култури средњег века и ренесансе. Служећи се компаративном методом и методом close reading анализирамо активан или пасиван однос Матавуљевих и Сремчевих јунака према јелу и пићу, као и начин на који се такви односи граде у наративној структури романа. Слике обиља снажно утичу на позициони-

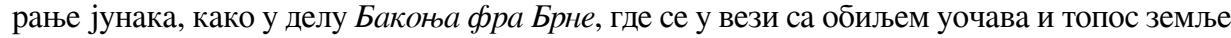
дембелије, тако и у роману Пой Ћира и йой Сйира где се јасније издвајају опозиције иманентне гозбеним сликама: „имати-немати” и „природно-вештачко”, односно „домаће-страно”. Циљ рада је указивање на многоструке функције и значај гозбених слика у анализираним романима како би се отвориле могућности за нова тумачења ових дела.

Клуччне речи: храна, пиће, комика, реализам, гозбене слике, хумор, Франсоа Рабле.

\section{УВОД}

Гозбене слике у романима српских реалиста Стевана Сремца и Симе Матавуља доносе ренесансни дух у виду раблеовских низова јела и пића који неретко представљају један од главних извора комике у делу. У студији

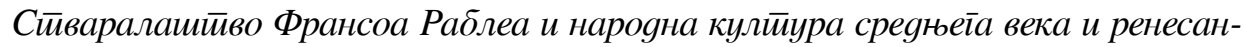

${ }^{1}$ Рад представља део истраживања у оквиру пројекта „Аспекти идентитета и њихово обликовање у српској књижевности” под евиденционим бројем 178005 на Филозофском факултету Универзитета у Новом Саду. 
ce Михаил Бахтин посвећује једно поглавље гозбеним сликама у роману и

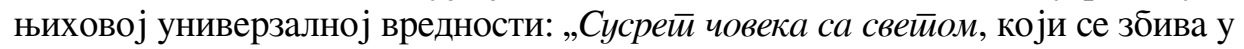
устима што су разјапљена, што једу, кидају и гутају, један је од најстаријих и средишњих сижеа људског мишљења и људских слика. Ту човек једе свет, куша укус света, уноси свет у своје тело, претвара га у део себе самог" (1978: 298). Сремчеви и Матавуљеви јунаци „кушају свет” на начин који одаје значај гозбених слика и захтева њихову детаљнију интерпретацију. Гастрокритика се углавном бавила делима француске књижевности, а проучавање функције хране у књижевним делима утемељено је на раним делима француског структурализма, пре свега Клода Леви-Строса, Ролана Барта и Пјера Бурдијеа (в. Павловић 2016: 2). Бавећи се у свом докторском раду гозбеним сликама у европском роману 19. века, П. Павловић уочава да метода француских структуралиста запоставља проблем психолошке мотивације и функцију књижевних детаља (2016: 2). У том контексту важно је његово запажање да „уз Симу Матавуља, Сремац од свих српских писаца највише заслужује да се назове српски Рабле” (Павловић 2016: 165). Сагледавање како индивидуалних тако и надиндивидуалних елемената гозбених слика постаје један од циљева и нашег рада, а уједно и критеријум за одабир метода истраживања.

У раду се служимо методама анализе и компарације, као и методом close reading која чини део феноменолошке методе, како бисмо на ексцерпираним примерима из романа успели да откријемо значење гозбених слика. У дефинисању термина „гозбена слика” служимо се Павловићевим објашњењем: „У нашем раду појам 'гозбена слика' означава семантички универзум уметнички представљеног заједничког догађаја, у којем се конституише и открива позиција тела у свету" (2016: 2). Позивајући се на средњовековну књижевност, француски историчар Ле Гоф наглашава како су одећа и храна у књижевним делима „упозоравали на друштвени положај ликова, симболизирали заплет, наглашавали значајне тренутке приче” (1993: 190). Сличну функцију храна заједно са пићем задржава и у каснијим књижевним раздобљима, при чему у реализму постаје и значајан извор комике, без нужног повезивања са карневалским контекстом и гротеском.

Павловићево истраживање приказује многострукост функција гозбених слика: „Писци 19. века представу о гозбеној слици и позицију тела у свету који је на њој најупадљивије изражен приказују на пет препознатљивих начина: друштвено одређивање, однос између тела и говора, начин презентовања гозбе, слике обиља и дочаравање представе о психолошкој мотивацији јунака" (2016: 5). Као основну функцију Павловић ипак види ону која се односи на сигнализацију реалности (2016: 5). Романи 19. века којима се

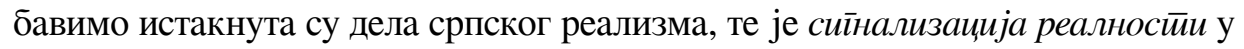
овим делима додатно интензивираног значења. Важност и заступљеност хране и пића у романима Стевана Сремца и Симе Матавуља већ су примећене и анализиране (в. нпр. Иконић 2013; Павловић 2016). Поређењем романа Пой 
Ћира и йой Сйира и Бакоња ффра Брне могуће је дати нови поглед на разноврсне функције јела и пића у наративним структурама ових дела уопште, које се у сличном контексту књижевне епохе испољавају на различите начине.

\section{ГОЗБЕНЕ СЛИКЕ У СТРУКТУРИ РОМАНА БАКОҢА ФРА БPHE}

Раблеовске црте у хумору Симе Матавуља препознају се у његовом приступу грађи, где се он не либи да је посматра хумористично-иронијски, уз детронизацију сакралног, пародирање црквеног и ласцивне елементе. Однос према храни и пићу значајан је везивни моменат Раблеовог и Матавуљевог дела. На самом почетку свог романа о ђаковању и постригу Бакоње Јерковића, Матавуљ открива још један начин пародирања какав се може наћи и у Рабле-

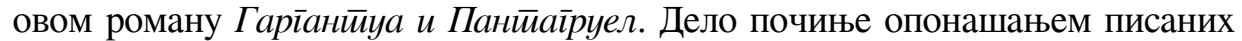
манастирских хроника, те се даје попис бискупа, опата, каптола, богословских семеништа и деканата у Далмацији ${ }^{2}$. Матавуљ даје породичну историју свете лозе, породице која даје фратре, коју обогаћује наводним цитатима усмених прича и анегдота о светој лози.

Ове анегдоте отварају се читаоцу податком о надимцима три гране свете лозе Јерковића. Надимке који на хумористичан начин обзнањују доминантне особине личности за које се везују искористио је и Стеван Сремац на почетку романа Пой Ћира и йой Cūupa. Матавуљев увод није мање духовит, те Јерковиће зову Брзокуси, Зубаци и Кркоте: „У почетку ће се подвући једна негативна особина, халапљивост, а касније ће репертоар надимака обухватити и друга својства, по правилу негативна" (Иванић 1990: 239). Аутор у извесном смислу оправдава смишљање ових надимака јер, како истиче: „Исти фратри, иако су, послије бога, највише штовани, не могу измаћи томе народњем крштењу" (Матавуљ 1991: 177). Како прелази на ужу карактеризацију породице Кушмеља из гране Брзокуса, Матавуљ не пропушта да напомене колико чланови породице могу појести и попити и колико стоке за клање породица поседује. За Јера Јерковића, на пример, писац истиче: „Могао је појести печено двизе, али пити је слабо могао” (Матавуљ 1991: 179). Имајући у виду да је gвизе име за двогодишњу овцу, читалац стиче слику о позамашном апетиту главе породице.

Насупрот томе, сиромаштво у којем Бакоњина породица живи носи са собом глад као константу његовог одрастања: „У роману Бакоња фра Брне слике изобиља преломљене су кроз перспективу гладног детета. Ту дечју

${ }^{2}$ Низање и „инвентарисање” чести су поступци у Раблеовом роману Гарїанӣууа и Пан$\bar{u} a \bar{p} y е л$, као и у романима Симе Матавуља и Стевана Сремца. 
перспективу Матавуљ је спојио са инфантилном визијом земље дембелије у којој су све гастрономске жеље задовољене" (Павловић 2016: 216). Доживљај „раја на земљи” другачији је од реалне слике манастира. Замишљени непресушни извори хране и пића описани су изразито поетски, упркос реалистично-ироничној визији реке крај манастира: „Ето вода кркља и као да у хиљаду лонаца ври купус" (Матавуљ 1991: 210). Ситост као мера свих ствари појављује се и у Бакоњиној мотивацији за одлазак у манастир: „Бакоња је мислио како је лијепо бити фратром! Како је лијепо јахати добра коња, водити уза се сејиза, носити чисто рубље, спавати на меку, у сувоти и топлини, јести меса и рибе, пити вина и кафе сваког боговетног дана!” Изобиље које мали Бакоња гледа у контрасту је са његовом гладном свакодневицом, те се на таквој подлози и гради његова визија о земљи дембелији у манастиру.

Бакоња ипак добија прилику да начини корак даље и изађе из свакодневице у којој се животари. Стриц фра Брне бира га да оде с њим у манастир и школује га за фратра. Пре него што овај избор начини пометњу у кући, пристигли Бакоњини стричеви пију и наздрављају. У таквој атмосфери средишњи мотив представља здравица једног од стричева у част фра Брновог доласка. Премда сачињена од многобројних вербалних комичних елемената, „индивидуалних говорних карактеристика, неологизама, дијалекатског говора, и нарочито поредбених алогизама, парадокса, понављања и паралелизама" (Максимовић 2003: 202), врхунац њене духовитости ипак је у чињеници да је неразумљива. Такав доказ Матавуљеве „смјехотворне ведрине” (Максимовић 2003: 422) није ипак без свог ширег семантичког потенцијала. Здравице су честе и у Раблеовом делу и представљају неизоставни део сваког колективног напијања. Ритуална ситуација наздрављања уводи мотиве пића и испијања, као и пуне трпезе, а утопичност гозбене речи о којој пише Бахтин живи управо у контексту здравице какву проналазимо и у роману: „будући тријумф човека приказује се у материјално-телесним сликама изобиља и обнављања човека" (1978: 303).

Здравица је уједно и моменат гозбеног тријумфа који неизбежно добија облик узношења најлепше будућности (в. Бахтин 1978: 303). За Бакоњу нови живот почиње доласком у манастир. Духовни профил дечака приказан је читаоцу кроз свежину дечје перцепције, а самим тим и онеобичене тачке гледишта (в. Бечановић 2006: 223). Први сусрет са фратрима у манастиру једна је од најефектнијих сцена у роману, додатно интензивирана снажним утисцима посматраним и вреднованим кроз Бакоњин дечији вредносни систем. Ту дечију перспективу писац је спојио са инфантилном визијом земље

${ }^{3}$ Топос земље дембелије у најкраћем се може објаснити формулацијом коју Павловић помиње у свом раду: „У западноевропској књижевности, Земља дембелија се представља као земља нестварног обиља" (2016: 215). У контексту гозбених слика, овај појам нам је важан као објашњење за начин на који Бакоња живот у манастиру идеализовано види као изобиље хране и пића. 
дембелије, у којој су све гастрономске жеље задовољене (в. Павловић 2016: 216). Прва слика фратара дата је тек у неколико реченица, али су њоме пластично приказани људи који у манастиру живе и наговештена визија изобиља: „Седам фратара извалило се на клупи под орасима. А какви су да се од бога нађу! Петорици се куља надула, свакоме једнако задригла шија, сваком једнако пуцају образи, сваки једнако отромбољио обријане усне. Двојица само бјеху мршави људи" (Матавуљ 1991: 200). Придеви и глаголи којима Матавуљ описује угојене фратре чине њихову облапорност и лењост још

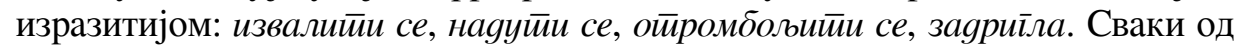
фратара поред свог црквеног имена има и надимак који је добио „по народном крштењу", а који га не описује ништа мање симптоматично од његовог изгледа (нпр. Блитвар, Дувало, Жвалоња). Истицање значаја хране за фратре у уводу у Бакоњин манастирски живот сигнал је за изузетну важност коју храна и пиће имају у животу целокупног манастирског живља.

Бакоњина иницијација у манастир такође је у знаку јела. Када му кувар донесе вечеру, он уморан и гладан ириону својски, изненађен што му шјор-Грго после доброг комада говедине носи и печење, салату, једну крушку и пуну чашу вина (Матавуљ 1991: 206). Да је овакав оброк за ђаке био заиста посебан, показује и податак да „иначе, по обичају, ђачки доручак бијаше комад хљеба" (Матавуљ 1991: 218)4. Окрепљеном Бакоњи следи затим нешто другачија иницијација. Нови другови га у ђачкој трпезарији подстичу да попије још вина, али када нагне чашу дочека га непријатно изненађење: у вино су му ставили паприку. Показавши снагу и храброст у отпору према оваквој врсти пакости, Бакоња започиње своје ђаковање као равноправан међу друговима. Нови облик иницијације у свом ђачком животу Бакоња доживљава „у Букарево вријеме”. Старији другови га позивају да са њима пређе преко зида, што има и своје дословно и метафоричко значење. Ђаци ноћу у тајности мрсе и храном и пићем, и веселе се са манастирском послугом. Иако се на почетку опире и осећа грижу савести, Бакоња се убрзо препушта овим, како му се чини, безазленим насладама младости. Како Максимовић истиче, „епизоде из живота манастирске послуге својеврсна су потврда виталистичке, руралне пројекције у роману Бакоња фра Брне и, више од тога, захваљујући лагоди и изобиљу, аутентично дионизијско славље живота" (2003: 207). Овакви видови дионизијских свечаности карактеристични су за Раблеов роман

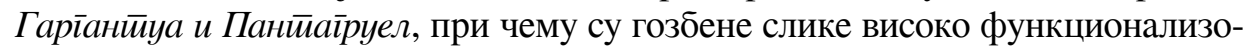

${ }^{4}$ П. Павловић се у својој докторској дисертацији о гозбеним сликама у европском роману 19. века дотиче и извора хране у фрањевачком манастиру о којем пише Матавуљ. Било да су слике изобиља позајмљене од Чосера, Бокача или неког другог сличног писца, важна је алузија на то да храна која се једе у самостану долази „ниоткуда”. Доказујући како реално стање у католичким манастирима у Далмацији није подразумевало обиље хране већ, евентуално, редовност и другачију структуру оброка, Павловић приказује како се фратарски живот може пре описати као гротескни сан о земљи дембелији (в. 2016: 217-221). 
ване у свеопштој прослави живота. За ђаке то искуство бива појачано услед забране јер они по први пут, налазећи се ван манастирских зидина, осећају како све врви од живота: точи се и пролива, игра се и пева. Ова прекомерност постаје још изразитија на констрастној подлози учмалог фратарског живота.

У складу са захтевом за прекомерним једењем и пијењем који се не сме изневерити, бира се жрйва способна да ову игру доведе до њених крајњих граница. За ђаке је то био Букар, нови коњушар, наизглед преплашен и приглуп. Слично сцени у роману Јакова Игњатовића Милан Наранцић, у којој ђаци у веселој кафанској атмосфери напијају формундера, односно тутора, док не заврши на столу, ђаци Букару непрестано говоре „још” док његово пијанство не достигне размере животињског („наду се као тенац”). То одговара основном карактеру карневала и гозбених слика у којима морају учествовати сви, без обзира на свој друштвени положај или функцију, а истовремено подвлачи укидање било каквих разлика, па и оних између људског и животињског.

Распојасана ноћна славља и уживање у мрсној гозби која је, у складу са закључком П. Павловића о измишљеном свету рајског изобиља у манастиру, могућно само део ноћних маштања гладног дечака, представљају јасно одељен свет где не важе уобичајена правила, попут бахтиновски схваћеног карневала. Стање општег расула, у којем фратри после велике похаре и пустошења цркве неумерено једу и пију, нема пак много од карневалске ведрине. Непосредно након похаре описане у поглављу „Ужас”, храна постаје мост између озбиљног и комичног, ванредног и уобичајеног. Храна, дакле, обележава сваку необичну ситуацију, свако време које добија особине свечаног, изузетног и другачијег. Истовремено, представља оазу и симбол утехе и сигурности.

Милан Кашанин уочава да Матавуљ својим хумором не хероизира мале људе као што то чини понекада Јаков Игњатовић у својим делима, већ их и умањује (2004: 140). Истиче, међутим, како је ,једина хероизирана личност у његову роману Бакоња фра Брне, за којега нема ироничних речи" (Кашанин 2004: 140). Инфантилни поглед на свет дечака са почетка дела бива у извесној мери неизмењен. Премда жељан дружења и радости, он израста у озбиљног и вредног младића, а његов дух остаје неискварен атмосфером у којој је живео. У последњој глави описано је како Бакоња, упркос разним искушењима, постаје фратар у варошици. Следствено томе, укида се могућност брачног спајања, али повезивање две вере, католичке и православне, доводи до гошћења налик на свадбену гозбу на крају романа Пой Ћира и йой Сūupa. Бакоњин амбивалентан однос према „ркаћима”, православнима, трансформише се на крају у присан пријатељски однос са попом Илијом. Пријатељство се крунише великом прославом код Бакоње фра Брна која наликује на карневалску „гозбу над гозбама”. 
Радња, дакле, завршава у веселом духу, при чему последње Бакоњине реченице у роману заокружују пишчеву тежњу да живот и људе прикаже без романтичарског заноса: „Сви кажу да сам добар човик, а ники кажу да сам рђав фратар! Може бити и једно и друго! Кад сам се родија, ја нисм избира шта ћу бити, а садак сам каквог ме дадоше бог и људи!” (Матавуљ 1991: 354). Готово свака људска слабост у роману, па и она према храни и пићу, дата је да прикаже „више смешну но жалосну слику људи који, зато што су се замонашили, нису престали бити људи" (Кашанин 2004: 140). Такво полазиште кључно је за тумачење функција гозбених слика у роману. Уколико се Бакоња фра Брне схвата више као „фасцинантно забаван роман но морално судиште” (Кашанин 2004: 141), лако је осетити живост и виталност која избија из сцена једења и пијења. Кашанин пише како је Матавуљев роман „радосна књига и сви људи у њој симпатични (и нама и писцу), иако, кад размислимо, нема толико разлога да нам буду симпатични, нити да се, заједно с писцем, толико смејемо" (2004: 142). Такав смех не би био могућ да револт, скопчан с манама недопустивим за фратре, није премошћен гозбеним сликама. Из њих избија животни нагон у свом најизворнијем облику: нагоном да се једе, пије и слави и када разлога за то има најмање.

\section{ФОРМИРАҢЕ ГОЗБЕНИХ СЛИКА У РОМАНУ ПОП ЋИРА И ПОП СПИРА}

Роман Пой Ћира и йой Сйира с правом се назива најведријим и најрадоснијим књижевним делом које је Сремац написао (в. нпр. Кашанин 2004: 163). Поред ликова који често „личе на велику децу” (Кашанин 2004: 156), динамичних дијалога и вешто изграђених хуморних сцена, ведрини овог дела свакако доприносе и веселе слике уживања у храни и пићу. У шаљивој слици војвођанског живота и менталитета, значајно место заузела је и војвођанска кухиња. Сам увод у причу о два попа, две попадије и њиховој свађи која је у роману превазишла размере комичне анегдоте, „заслађен” је карактеризацијом попова у којој доминирају крофне: „'Господин-домине - обратив се Кипри нотарошу - молим вас лепо, мало од оних крофни из онога тањира тамо, чини ми се да су те тамо мало руменије а боље нарасле.' - А сваки поп чудо што воли крофне! Откуд сад то, бог ће га свети знати; али то је непобитан фактор, познат сваком правом сину наше свете православне цркве" (Сремац 1977: 26). Даље следи сужавање карактеризације на поп-Ћиру и његову халапљивост, посебно на једној свадби где је појео пуну вешкорпу крофни. Док домаћица зајапурена прави крофне, он их иза њених леђа једе, што доводи до комичног нестанка посластице.

Таква љубав према крофнама само је потврда поп-Ћирине слаткохраности која оправдава његов надимак у селу - поп Хала. Ни други поп не 
остаје без свог амблематичног надимка, па тако поп-Спиру зову поп Кеса због његове видне похлепе. Управо очигледност и једне и друге мане сажете у надимке, атипичне за свештена лица, доводи до смеха који превазилази пуку критику. Кашанин запажа: „Била би заблуда помишљати да је Сремац писао овај роман ради тога да се подсмехне православном клиру” (2004: 163). Он примећује и одсуство Сремчеве аверзије према двојици свештеника, односно симпатију према њима. Такав пишчев став омогућује и веће уживање у бројним гозбеним сликама у роману, имајући у виду да њихова функција није усмерена само на доказивање непримерене прождрљивости попова. У анегдоти о поп-Ћирином изузетном апетиту уведен је и прототип домаћице. Безимена домаћица у чијим крофнама поп ужива описана је само једном реченицом где је она сведена на две карактеристике: она пече крофне и бива задовољна због тога што је њен једини циљ да пронађе зета сада достигнут. Такве особине својствене су обема попадијама. Оне се у истом поглављу „појављују у разговору на тему печења колача, у ком је спретност у кухињи подигнута на ниво услова успешног брака" (Стојановић 2006: 251).

Однос према храни представља и један од услова успешних суседских односа. Да би описао како су попови међу собом живели „врло лепо”, писац се користи техником низања хране, примећеној и у Матавуљевом роману: „Кад поп Спира закоље свињу и направи диснотор (што ће рећи свињску даћу), а он прво пошље поп-Ћири од заклатог свинчета и кожурице и масти и кобасице и крвавице, па понекад и неку шварглу, ма и најмању; тако исто ради и поп Ћира и шаље поп-Спири" (Сремац 1977: 36). Разлог зашто попадије следе њихов пример и шаљу једна другој „милихброт, торту, штрудлу, куглоф и томе подобна теста" посве је другачији. То открива и њихове карактере, као и природу њиховог односа, па тако Ћириница говори: „Знам да ће пући од једа госпођа Сида кад само види како је добар мој квасац! Па кернштрудла лепо нарасла, па мекана к'о душа" (Сремац 1977: 36). Почетне романескне главе тако су у знаку „дискретног карикирања свакодневног живота банатског села, а тиме и увођења и мотивисања стварног комичног заплета” (Максимовић 2003: 180). Завист и надметање у односу госпође Персе и госпође Сиде, присутно и у ритуалу слања хране, интензивира се током романа и доводи до заплета. Када попадије почну да се надмећу око будућег зета, учитеља Петра Петровића који долази у село, суседска идила доживљава све веће поремећаје. Приликом Периног првог одласка у госте код поп-Спире и госпође Сиде, он говори о својој идеалној жени и животу какав би волео да живи, при чему велику улогу поново има храна: „Проста кујна, скромна, проста али укусна јела; каква пилећа чорба, паприка са ноклицама и једна српска гужвара - па више не тражим да једна домаћица уме свом мужу зготовити ручак” (Сремац 1977: 67).

Учитељ Пера дочекује најзад „једну српску гужвару” на ручку код поп-Спире, и то справљену управо Јулином руком, након чега настаје опште 
хваљење пите, њене масноће и финог укуса. Овакве сцене у роману показују да је реч о јунацима који имају активан однос према храни: „Гозбене слике могу послужити и за то да се прикаже психолошки карактер односа јунаковог тела према свету који га окружује. Овај однос конкретизује се представом о жељи: у складу с тим, однос може бити представљен као однос активне или пасивне природе. [...] Активан однос приказан је као уживање у храни или као жеља за поседовањем. Пасивни однос представљен је као неприхватање 'приказаног света' и тежња ка неком невидљивом свету - свету духа" (Павловић 2016: 325).

Имајући то у виду, постаје јасно и инсистирање јунака Сремчевог романа на домаћој храни. Попадија Сида са гађењем говори о јеврејским јелима: „Што баш у нашу недељу да тамо руча [учитељ Пера], да једе леб с кимом и друга чифуцка јела?!” (Сремац 1977: 67). И поп Спира дели мишљење своје попадије о јелима страних кухиња, те тако писац истиче да он „није марио за поковано пилеће; као Србин и православне цркве син, мрзео је на то швапско печење, и чекао је гужвару, омиљено своје јело” (Сремац 1977: 90). Отпор према страној кухињи испоставља се тако као неприхватање читавог једног света и остајање у домену свог, изворног, домаћег. С друге стране, присутно је и поистовећивање самих ликова са храном, што се манифестује управо кроз укус учитеља Пере: јела која су по његовом укусу проста су и скромна, а таква је и Јула у коју се заљубљује. Оваква врста идентификације јунака и хране није реткост у књижевности и представља доследно спроведену карневалску тежњу брисања граница између тела и спољашњег света. У исто време, и сам аутор прекорачује естетске границе описивањем непредстављивих чулних доживљаја, као што су мирис и укус хране, али и нагомилавањем визуелних утисака у гозбеним сликама (в. Павловић 2016: 253).

Овакви чулни утисци претварају се у појединим моментима у лирске минијатуре - апотеозе, при чему се поново исказује поштовање према домаћем, у овом примеру пићу: „Волео је г. Пера као сваки богословац шљивовицу. Колико је пута уз њу певао јој онај свима бословима тако добро познати тропар шљивовици: 'Пресвјатаја мученице, препеченице"' (Сремац 1977: 70). У овој похвали „чрезвичајној сремачкој шљивовици” нема инверзије профаног и сакралног, већ само њиховог преплитања. За разлику од Матавуљевог дела, у Сремчевом роману, и поред пишчевог поигравања са сакралним, оно никада не бива сасвим посувраћено на своје наличје ${ }^{5}$. Нема, такође, ни покушаја да се на место уживања у јелу и пићу постави аскеза као примерно понашање свештеника и богослова. С тим у складу, сем фине ироније, нема осуђивања богословске љубави према алкохолу. Сам поп Спира ужива у добром пићу. Код њега је разговор могућ тек након ручка, уз квалитетно

${ }^{5}$ Треба имати у виду да су код Раблеа „описи претеривања калуђера у јелу у пићу првенствено сатирички-антиклерикално инспирисани” (Лазичић 2009: 153). 
вино: „Поп Спира је био прилична ћуталица и иначе, а кад је јео држао се оног златног Доситејевог правила: 'Кад једеш - једи, а не разговарај ни са ким" (Сремац 1977: 90). Вино опушта и ствара атмосферу веселог разговора, а насупрот уобичајеним хришћанским принципима трпљења и патње, поп-Спирино правило је да човек буде весео. Из таквог става избија ренесансна веселост и позната крилатица „саrpe diem”, што се слаже са раблеовским изједначавањем карневализма и животне ведрине.

Пиће је уз то и знак надахнућа, те тако не изненађује што у роману Пой Ћира и йой Сӣupa свако окупљање и сваки слободнији и веселији разговор мора бити пропраћен пићем. Павловић истиче: „Слично као и одбијање хране, одбијање пића симболизује неприхватање одређеног система знакова, али, за разлику од одбијања хране, има још једну симболичку димензију, а то је немогућност да се осети и проживи надахнуће. Ова димензија усложњава представу о одбијању. У романтичарској поезији и прози опијање алкохолом - најчешће вином и пунчом - производи надахнуће које јунака одводи у неки други, лепши свет" (2016: 313). Надахнуће у Сремчевом роману нема своју конкретизацију у виду стварања неког уметничког дела, али оно свакако производи надахнуће које јунаке одводи у лепши и веселији свет. На овај начин, Сремчева реалистичка проза благо је прожета романтичарским тоновима 6 . Повезаност са ренесансом, међутим, много је очитија, па је тако, као и у Држићевом Дунgу Мароју, ренесансна живост „најексплицитније приказана у ужитку једења, у радости тијела ослобођена од гријеха неумјерености у јелу и пићу”, а „мотиви прехране стоје у функцији смијеха једнако колико и етике” (Иванишевић 2011: 24). У складу с тим је и последња реч Раблеовог романа

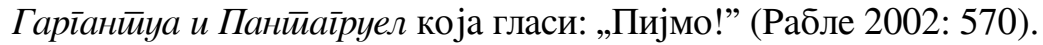

Добар апетит, па и склоност ка чашици, својствени су свима у роману сем Меланији, што свакако није без свог семантичког значаја: она је више окренута „свету духа” (воли да чита, свира клавир). Меланија је зато један од ретких ликова у роману који имају пасиван однос према храни. Није, ипак, дато свим ликовима у роману да уживају у богатој трпези као што то чине попови и њихови гости. Тек у понекој реченици, наизглед успутно, осликава се и друга страна друштвене ситуације банатског села крајем 19. века. Попут слуга у ренесансним комедијама, а посебно у већ поменутом Дунgy Мароју где је аутентично приказана Пометова жудња за храном и пићем, у кућама поп-Ћире и поп-Спире слуге се на разне начине довијају да дођу до хране. Своју слушкињу, Жужу, госпођа Сида „никад није уштинула за образ, него

${ }^{6}$ У вези са упливом романтичарског, односно отклоном од истог, треба напоменути: „Поетички лик сентименталног и романтичарског романа, бахтиновски речено, обележили су јунаци заражени 'антифизисом' - јунаци који нису 'од овога света', који, између осталог, никада не једу. Зато је обликовање књижевних јунака који су 'живи људи' и увођење у романескни свет низова хране и пића битан елемент разградње романтичарске и почетак конституисања реалистичке поетике" (Лазичић 2009: 152). 
је, шта више, често грдила и називала је леном девојчуром што дању поваздан дрема, а ноћу краде маст и пече крадом лукумиће кад сви по кући заспе” (Сремац 1977: 65). Да ли је Жужа заиста халапљива готованка или је само гладна Сремац не експлицира, али је индикативна његова констатација да се у опису ове ситуације служи „сопственим речима госпоја Сиде” (Сремац 1977: 65). Социјална неједнакост није приказана само на основној опозитној равни - гладне слуге и сите газде - већ се манифестује и кроз специфичан укус слуга, па тако, на пример, ни „Помету није пресудна количина хране којом тажи глад, него окус и жеља за храном, којом се показује сталешка припадност" (Иванишевић 2011: 16). Имајући у виду да је лукум слаткиш, врста колача, ова теза испоставља се као тачна и у случају слушкиње Жуже.

Аналогно гозби на крају романа Бакоња бра Брне, роман Пой Ћира и

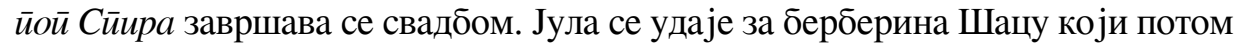
одлази у Беч и постаје зубар. Њихова љубав развија се упоредо са свађом између попова, као и са везом која се гради између Меланије и Петра. Јулина и Шацина љубав је здрава, природна и једноставна, а тако изгледа и остало за шта се писац у делу залаже. Ништа помодарско ни извештачено у роману није афирмисано, од хране која је на трпези до девојачких особина. Не чуди отуда што је и Јулин и Шацин брак прослављен йравом срйском сваgбом са разноврсним јелима. Да је тако потврђује и штиво које је госпођи Сиди послужило да направи „сјајан и обилан ручак, којега су сви гости и пулгери па и беамтери хвалили" (Сремац 1977: 325): Срӣски кувар јеромонаха крушедолског Јеротеја. Реч је о личном кувару патријарха Рајачића, Јеротеју Драгановићу, који је 1855. године у новосадској штампарији Игњата Фукса штампао Срйски кувар, иначе други међу Србима (в. Иконић 2013: 117). Индикативно је што је овај „веома цењени приручник за кулинарске вештине постао ствар престижа”, као и чињеница да га је свака врсна домаћица која је држала до себе морала поседовати (Иконић 2013: 117).

У опису свадбе, међутим, више од низања конкретних јела истиче се обиље, а сам аутор шаљиво оправдава изостављање детаљнијег описа свадбеног ручка: „Сам ручак нећу описивати јер признајем да је лепше и лакше бити позван на ручак него га описивати" (Сремац 1977: 325). На тај начин постаје уочљивији императив припремања свадбене трпезе, а то је да свега буде више и боље него што је било на Периној и Меланијиној свадби. Весеље у поп-Спириној авлији личи на сваку раблеовску прославу: „Сврши се венчање и сватови се вратише, заобишавши далеко унаоколо, вратише се још бешње но што су отишли. Ухвати се у коло и звано и незвано: млађи играју, а старији се обређују шљивовицом (која је Јулиних година), а Нића боктер и пије и игра" (Сремац 1977: 325). Карневалска атмосфера свадбе смирује се на крају романа меланхоличним епилогом. Учитељ Петар, сада ђакон, наилази на Јулу у једној вароши у Бачкој. Идилична слика мајке са четворо деце изазива у Петру дивљење, али и тихо жаљење што за жену није одабрао 
њу. Сетан завршетак овог, у основи хумористичног романа, показује да је Стеван Сремац непретенциозно успео да разобличи једноличан механизам малограђанског, ситничавог и површног начина живота.

Следећи линију модерног реалистичког приповедања, роман Пой Ћupa и йой Cйupa, заједно са романом Бакоња фрра Брне Симе Матавуља, остварио је значајан помак у српској књижевности и допринео њеном бржем ослобађању приповедачких клишеа романтичарско-сентименталистичког порекла (в. Вукићевић 2003: 78). Гозбене слике и хедонистички приступ јунака храни и пићу учинили су да српска књижевност буде ведрија и богатија за један оригиналан приступ људском менталитету. Стеван Сремац није пропустио да уз „уздржану иронију и благ хумор с прелазом у меланхолију и сатиру” (Кашанин 2004: 156) опише како се хране, пију и веселе паори, беамтери, попови. Дубина и креативност пишчеве инвенције приказују се у својој пуноћи управо када Сремац описује деликатесе у којима уживају мештани једног војвођанског села. Јела и пића која поједини ликови бирају на занимљив начин сигнализују шта је оно што је тим ликовима важно. Без таквог и на такав начин добијеног увида, дело би било сиромашније: „Храна је у роману не само откривалачки атрибут социјалних односа, него и индивидуални одговор Сремчевих јунака према животу и свету” (Иконић 2013: 121). Стеван Сремац успео је гозбеним сликама да ликове свог романа учини живљим, истинитијим и људскијим, а читаоце пријемчивијим за радост и ведрину које његов роман нуди.

\section{ЗАКЉУЧАК}

Романи Симе Матавуља и Стевана Сремца нуде гозбене слике као карике које творе чврст ланац њиховог смехотворног стваралаштва (в. Иконић 2013: 121). Иако у прози, они су дати у духу дитирамбске поезије која слави живот и тежи да га обухвати у мери која поништава страх да се такав радостан и пун живот обухвати, односно - прогута. Оба дела потврђују следећу тезу: „У роману 19. века гозбене слике се јављају као веома ефектно средство проблематизовања односа између представе о људском телу и представе о друштвеном одређивању, психолошкој мотивацији, начину презентовања гозбе и памћењу гозбе као жанра" (Павловић 2016: 323). При томе се као неизоставни елемент код оба писца појављује хумор. Разлози за тумачење гозбених слика произлазе из фреквентности оваквих слика у анализираним романима, али и из предности које су им иманентне: „Предност гозбених слика у односу на неке друге могуће слике јесте у томе што се у њима људско тело и представа о класним односима доводе у везу с контрастом 'имати-немати' и 'природно-вештачко"' (Павловић 2016: 323). Ови оштри опозити ублажени су тежњом да се здрав смех испостави на место отровне огорчености, а весело 
уживање на место лажног аскетизма. Матавуљ и Сремац служе се сликама гозбе да би приказали „деликатне односе између људског тела, света естетске илузије и свакодневног живота”, при чему се ти односи апострофирају алузијама на мирис и укус хране која је приказана као естетски објекат (Павловић 2016: 323). Било да обиље припада имагинарном простору земље дембелије, или је његова улога да успостави границе између оних који имају и оних који немају, важно је пажљиво критичко-функционално позиционирање гозбених слика у делима Бакоња ффра Брне и Пой Ћира и йой Сйupa, како би се дао подстицај за нове и иновативне приступе овим романима.

\section{ИЗВОРИ} Prosvjeta.

Матавуљ (1991): Simo Matavulj, Bakonja fra Brne, u: Sabrana djela I, Zagreb:

Сремац (1977): Стеван Сремац, Пой Ћира и йой Сӣира, Лимунација у селу, Београд: Просвета.

\section{ЛИТЕРАТУРА}

Бахтин (1978): Mihail Bahtin, Stvaralaštvo Fransoa Rablea i narodna kultura srednjega veka i renesanse, Beograd: Nolit.

Бечановић (2006): Татјана Бечановић, Инфантилна тачка гледишта као извор хумора у Матавуљевом роману Бакоња фра Брне, Међународни научни сасйанак славистиа у Вукове gане, 35, Београд: Међународни славистички центар, 221-233.

Вукићевић (2003): Драгана Вукићевић, Оіллеgи о срйском реализму, Краљево: Народна библиотека „Стефан Првовенчани”.

Иванић (1990): Душан Иванић, Моgели књижевноїа йовора, Београд: Нолит.

Иванишевић (2011): Jelena Ivanišević, Lačan ne haje toliko za ljubav: Gastronomija Dunda Maroja između srednjovjekovlja i renesanse, Anali Dubrovnik, 49, 9-25.

Иконић (2013): Ивана Иконић, Калорије из Срйског̆ кувара на трпези Пой Ћире

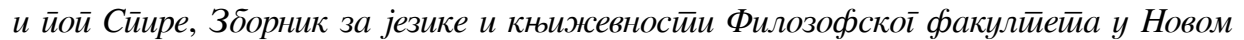
Cagy, 3, Нови Сад: Филозофски факултет, 117-130.

Кашанин (2004): Милан Кашанин, Суgбине и љуgи: оїлеgи о срӣским ӣисцима, Београд: Завод за уџбенике и наставна средства.

Лазичић (2009): Горан Лазичић, Смех (не) гоји (о природи комичног и калоричног у романима Стевана Сремца Пой Ћира и йой Сйира и Ивкова слава), Граяина, XLV, 28, Ниш: Културно-просветна заједница општине, 151-156.

Ле Гоф (1993): Žak Le Gof, Srednjovjekovni imaginarij: eseji, Zagreb: Izdanja Antibarbarus.

Максимовић (2003): Горан Максимовић, Тријумфб смијеха, Ниш: Просвета.

Павловић (2016): Павле Павловић, Гозбене слике у евройском роману gевей-

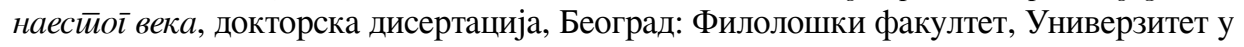
Београду. 
Стојановић (2006): Олга Стојановић, Од шаљиве анегдоте до реалистичког романа: путеви наративне конституције у Сремчевом Пой Ћири и йой Сйири, Међунарояни научни сасйанак слависйа у Вукове gане, 35, Београд: Међународни славистички центар, 245-257.

\section{Sanja P. Perić}

University of Novi Sad

Faculty of Philosophy

$\mathrm{PhD}$ student

\section{FEASTING IMAGERY IN THE NOVELS POP ĆIRA I POP SPIRA BY STEVAN SREMAC AND BAKONJA FRA BRNE BY SIMO MATAVULJ}

Summary: The paper analyzes banquet pictures in the novels by Simo Matavulj and Stevan Sremac, Serbian 19th century realist authors, with the focus on the relation between banquet images and characters who (do not) enjoy the feast. The ambiguity and multifacetedness of gastronomic themes in the novels raises the question of the functionality of the feasting images and the ways they are displayed, both on the micro-plane of the literary work and in the wider context of European literature. In this context, it is important to highlight Rabelais's novel, as well as Bakhtin's analysis of feasting images in the novel and folk culture of the Middle Ages and the Renaissance. Using a comparative method and a close reading method, the existence of an active or passive relationship of Matavulj's and Sremac's characters with food and drink is analysed, as well as the way such relationships are constructed in the narrative structure of the novels. Images of abundance strongly influence the positioning of the main character, both in the novel Bakonja fra Brne, where the literary topos of an eldorado is present, and in the novel Pop Cira and Pop Spira, where the oppositions immanent to the feasting images are more clearly distinguished: "to have-not to have", "natural-artificial" or "domestic-foreign". The aim of the paper is to point out numerous functions and significance of the feasting images in the novels in order to open up possibilities for further analysis.

Keywords: food, drink, comedy, realism, feasting imagery, humour, François Rabelais. 